\title{
Penerapan dan Manfaat Sistem Informasi Manajemen pada Pembelajaran Sekolah Menengah Kejuruan
}

\author{
Handi Wahyudi \\ Universitas Negeri Padang \\ Indonesia \\ E-mail : handiwahyudi12@gmail.com
}

\begin{abstract}
Abstrak-Penulisan ini bertujuan memberikan pengetahuan dan wawasan mengenai pengetahui dan menambah wawasan mengenai manfaat sistem informasi manajemen di sekolah manajemen kejuruan. Yang mana data dapat dikumpulan melalui pengumpulan data dari sumber - sumber yang konkrit, dimana dibhas salah satu pemanfaatan sistem informasi manajemen yang digunakan dalam pembelajaran di sekolah manajemen kejuruan yaitu seperti website dan elearning yang membantu dalam pembelajaran seperti mengaupdatan materi pembelajaran, mendownload materi pembelajaran dan penguploadtan, serta memasukan data - data evaluasi pembelajaran siswa melalui website yang telah ditentukan
\end{abstract}

Keywords - manfaat, sistem informasi manajemen, pembelajaran.

\section{Pendahuluan}

Lembaga pendidikan dapat dikatakan hidup apabila pengelolaan data dapat dilakukan terus menerusa dan pengelolaan data nya baik. Maka dapat dikatakan informasi ini merupakan salah satu sumber daya yang merupakan pondasi atau senjata utama dalam suatu lembaga maupun organisasi. Sistem informas manajemen merupakan suatu perilaku organisasi yang mana perilaku tersebur berupa perencanaan , pelaksanaan, pengawsan serta pembinaan sumber daya yang ada yang dilakukan dengan efektif dan efesien.

Sekolah menengah kejuruan juga dapat meningkatkan mutu nya baik itu melalui peserta didik maupun pendidiknya sendiri, dengan melakukan berbagai usaha yaitu dengan mengunakan teknologi yang lebih maju lagi sehingga todak ketertinggalan, mengembang kan kurikulum dan materi pembelajaran serta dengan memberikan diklat ke setiap sumber daya manusia yang ada.

Ada beberapa keunggulan dan beberapa kelemahan yang terdapat di sekolah menengah kejuruan dalam penerapan sistem informasi manajemen, dalam mencapai pemanfaatan sistem informasi manajemen di sekolah menengah kejuruan maka tidak luput pula kita memerhatika pengelolaan sistem informasinya dan tujuan pembelajarannya apakah sudah tercapai atau belum.
Banayak para ahli yang medefenisikan apa itu sistem informasi manajemen dan dengan memiliki batasan - batasan dari setiap mereka. Dari batasan - batasan tersebut maka dapat di ambil kesimpulan bahwasanya yang dimaksud dengan sistem informasi manajemen yaitu suatu sistem yang bertugas atau berperan sebagai penyedia bahan - bahan yang disebut dengan informasi/ data yang diperlukan oleh orang lain, dan dapat memengaruhi operasi komputer.

Sebelum adanya kompuer, sistem informasi manajemen tetap berjalan secara manual yang mana informasi atau data tersebut langsung diterima oleh manajer, sedangkan dengan komputer maka akan lebih banyak keuntungan yang didapatkan, seperti kecepatan ketelitian dan volume penyimpanan. Maka dengan adanya non komputer dan komputer maka terciptanya sistem informasi manajemen yang kompleks yang dapat menyediakan informasi baik ke manajer, pimpinan atau semua orang yang membutuhkan.

Dalam penerapan dan pemanfaat sistem informasi manajemen maka sangat diperlukan fungsi - fungsi manajemen mulai dari perencanaan sampai evaluasi.maka dari itu penerapan manajemen sebagai proses terhadap sistem informasi manajemen adalah penerapan fungsi-fungsi manajemen, yaitu perencanaan, pengorganisasian, penggerakkan, dan pengawasan yang dilakukan dalam setiap kegiatan informasi manajemen (Prasojo, 2013)

\section{Metode PENELITIAN}

Artikel ini ditulis untuk memberikan pengetahuan dan penambahan wawasan, dan penulisan ini didapatkan melalui pengumpulan berbagai kajian literatur dan Pengumpulan data dilakukan dengan menggunakan teknik dokumentasi. Selanjutnya data dianalisis dengan menggunakan tiga alur, yaitu: reduksi data, penyajian data, dan penarikan simpulan. Data yang didapatkan dari pengumpulan data - data yang bersifat kuantitatif.

\section{KAJIAN TEORI DAN PEMBAHASAN}

\section{A. Pengertian Sistem Informasi Manajemen}

Sistim informasi manjemen merupakan suatu wadah untu mengalirkan informasi yang dapat dipergunakan oleh 
berbagai orang maupun suatu organisasi. Arus informasi sama pentingnya dengan suatu kehidupan maupun kesehatan seseorang bahkan perilaku organisasi selalu ketergantungan terhadpa suatu informasi.

Menurut (Vindi Agustiandra, 2019) Sistem informasi manajemen merupakan berbagai komponen yang saling berkaitan. Sitem informasi manajemen merupakan suatu perangkat sebuah organisasi maupun lembaga yang menjadi pendukung bagi jalannya kelancaran organisasi tersebut dan sebagi pendukung tercapainya tujaun yang telah ditetapkan. Sistim informasi manajemen ini terbagi menjadi 2 baik secara manual maupun teknologi seperti komputer, sisitm berbasis komputer yang merancang dan membuat informasi bagi para pengguna yang memiliki kebutuhan yang diperlukan.

Informasi yang diberikan oleh sistim informasi manajemen memberikan gambaran atau sistim utamanya dilihat dari apa yang telah terjadi pada masa lalu, yang sedang terjadi, masa depan.

Sistem informasi manajemen berupa dokumen, datadata yang dapat dimanfaatkan oleh manusia dan dapat membantu merancang strategi dari organisasi yang bersangkutan, sistim informasi manjemen merupakan, komponen dalam organisasi yang mulai dari penciptaan sampai aliran evaluasi.

\section{B. Tujuan Pelaksanaan Sistem Informasi Manajemen}

Sistem informasi manajemen ini, memiliki tujuan umum yaitu untuk membantu memberikan berbagai informasi maupun data yang dibutuhkan oleh individu, kelompok maupun organisasi yang dapat menunjang keberhasilan dari organisasi tersebut.

Informasi yang diberikan secara tepat dan konkret dari mana sumber nya dan dapat dipercaya, sehingga tidak ada hoax yang bertebaran. Informasi yang efektf adalah informasi yang tepat waktu saat dibutuhkan. Dengan adanya sistem informasi manajemen maka informasi yang dikeluarkan itu terorganisasi atau termanajemen dengan baik, mulai dari melakukan perencanaan, pelaksanaan, pengendalian, pengawasan dan evaluasi.

Dan yang terpenting sistem informasi ini berbeda dengan manajemen informasi yang mana sistem informasi manajemen ini bertujuan untuk menyediakan informasi yang dibutuhkan oleh suatu organisasi untuk mencapai keberhasilan dari organisasi tersebut, sedangkan manajemen informasi itu adalah mengatur segala bentuk informasi.

\section{Pemanfaatan Sistem Informasi Manajemen dalam Perencanaan Pembelajaran}

Menurut DeLone \& McLean (Milka, 2014) dalam mengatakan bahwa sistem informasi manajemen dalam perencanaan pembelajaran itu difokukan kepada berapa sering sistem informasi tersebut digunakan. Ada beberapa macam sistem informasi yang digunakan oleh para guru di sekolah menegah kejuruan diantaranya yaitu website, elearning dan lain - lainnya.

Yang terpenting dalam perencanaan sistem informasi manajemen di SMK yaitu kepuasan penggunanya ( guru ), jika pengguna sering memakai sistem informasi tersebut maka pengguna tersebut telah yakin dan percaya akan sistem informasi tersebut, dan dapat dikatakan bahwasanya sistem informasi tersebut dapat memnuhi segala bentuk kebutuhan yang di harapkan oleh penggunanya (Milka, 2014).

Sistem informasi manajemen sangat dibutuhkan dalam perencanaan pembelajaran di sekolah yang mana dengan adanya sistem inforasi maka informasi tersebut akan selalu update dan tidak kurang nilainya sehingga selalu segar dan tidak akan usang. Dan sistem informasi harus relevan dengan waktu responnya sehingga berbanding sejalan dan cepat sesuai dengan kebutuhan para penggunanya.

Dengan melakukan perencanaan sistem informasi manajemen yang sudah matang dan baik maka akan menciptakan kepuasan sendiri bagi penggunanya dan kepercayaan dari penggunanya dan mengakibatkan sistem informasi tersebut akan berjalan efekti dan efesien.

\section{Pemanfaatan Sistem Informasi Manajemen dalam Pelaksanaan dan Pengawasan Pembelajaran}

Sistem informasi manajemen harusnya memiliki kesesuaian antara informasi yang akan disampaikan dengan waktu yang dibutuhkan, dalam pelaksanaan pembelajaran di sekolah menengah kejuruan sistem informasi ini digunakan oleh para guru - guru di sekolah tersebut untuk mencari dan mendapatkan materi pembelajaran yang akan di berikan atau disampaikan kepada para siswanya, contohnya saja melalui elearning, dimana dengan menggunakan sistem informasi manajemen seperti elearning maka itu dapat juga sebagai sistem yang akan membantu siswa belajar dengan baik walau pembelajaran ada guru nya atau tidak.

Penggunaan elearning di sekolah kejuruan sudah berjalan baik, dimana elearning ini memiliki beberapa kelebihan dimana baik data maupun informasi tersimpan dengan baik dan penyampaian informasi pun juga baik, elearning ini gabungan dari berinteraksi, pendownloadtan dan lain lainnya.

Elaerning ini adalah sistem informasi elektronik yang berhubungan dengan LAN, WAN dan juga internet. Elearning memiliki beberapa karakteristik diantaranya yaitu berbasis teknologi dan internetyang mana penggunanya yaitu para guru dan siswanya dapat berhubungan dan berkomunikasi dengan baik dan mudah, data yang disimpan maupun yang diupload dapat terjaga dengan baik, mengnai kurikulum, mata pelajaran dapat di lihat selau di komputer.

\section{E. Pemanfaatan Sistem Informasi Manajemen dalam Evaluasi Pembelajaran}

Pada saat evaluasi pembelajaran terkhususnya di sekolah menengah kejuruan yang dilakukan ialah mengupdate data dan informasi para peserta didiknya ke dalam suatu website yang mana data dan informasi tersebut akan sampai ke pusat. Nilai peserta didik yang akan di upload dan di update tersebut seperti nilai ujian tengan semester, ujian akhir semester, ujian sekolah, ujian nasional dalan lain - lainya.

Dengan adanya sistem informasi manajemen yang berbasis teknologi ini maka mempermudah para pemimpin lembaga pendidikan dalam mengumpulkan data, dan mencek 
data tersebut, sehingga dapat dikatakan berjalan dengan efekti fan efesien.

\section{KESIMPULAN}

Banyak sekali manfaat yang di daptkan dari penerapan sistem informasi manajemen dalam pembelajaran di SMK yang mana dengan adanya sistem informasi data kita dapat memanage atau mengorganisasikan, mengatur segala informasi yang didaptkan dan membantu pembelajaran di sekolah menengah kejuruan tersebut.

Sistem informasi yang digunakan yaitu berbentuk website maupun elearning, yang mana dengan bantuan sistem informasi berbasis teknologi ini maka data dan informasi yang dibutuhkan maupun yang akan di kirim ke pusat dapat terbantu atau dapat berjalan dengan efektif dan efesien.

\section{Daftar Pustaka}

Milka. (2014). PEMANFAATAN SISTEM INFORMASI MANAJEMEN DI SEKOLAH MENENGAH KEJURUAN. Jurnal Keguruan Dan Ilmu Pendidikan, III(1), 481-493.

Prasojo, L. D. (2013). sistem informasi manajemen pendidikan.

Vindi Agustiandra, A. S. (2019). PENERAPAN SISTEM INFORMASI MANAJEMEN PENDIDIKAN DALAM PROSES PEMBELAJARAN DI SMP NEGERI 21 MAKASSAR. Jurnal Bahana Manajemen Pendidikan, 8(1), 1-8. Retrieved from http://ejournal.unp.ac.id/index.php/bahana/article/view/1 03704/p 